\title{
Metaphorical conceptualization in national sports
}

\author{
Claudia Fedorova ${ }^{1, *}$, Vasily Argounov ${ }^{2}$ \\ ${ }^{1}$ North-Eastern Federal University, Department of English and Regional Studies, 58, Belinsky Street, Yakutsk, 677000, Russia \\ ${ }^{2}$ North-Eastern Federal University, Junior Researcher, Arctic Linguistic Ecology International Research Laboratory, \\ 42, Kulakovsky Street, Yakutsk, 677013, Russia
}

\begin{abstract}
The article addresses a number of issues in the study of conceptual metaphors related to their nature, typology, and functioning in various discourses. Metaphorical conceptualization on the material of the Yakut language has not so far been systematically explored in the cognitive linguistics literature on metaphor. On the basis of the theoretical framework of conceptual metaphor theory, the paper analyses creative and frozen metaphors and their systematic interconnection during conceptualization in sports discourse. The basic metaphor of sports discourse SPORT IS WAR is frequently elaborated by metaphorical nominations, such as "bootur" (ancient Yakut warriors), "soldaty" (soldiers), etc. In national sports, conceptual metaphors vividly and expressively reflect the specificity of not only the language, but also the history, traditions, and the metaphorical conceptualization of a particular ethnos.
\end{abstract}

\section{Introduction}

The problem field of cognitive studies of metaphor includes the mechanism of metaphor generation and its systematic nature. However, studies of the nature and typology of metaphors were largely conducted on the basis of lingua francas. The national and cultural specificity of metaphorical conceptualization has not been dealt with in-depth. The aim of the research was therefore to reveal the specificity of conceptual metaphors used in national sports on the material of the Yakut language.

The materials analyzed were Russian-language articles from traditional regional printed newspaper "Sport Yakutii" (Sport of Yakutia) and Yakut-language reports from the official YouTube channel "NVK Sakha". The national sports tournament "The Games of Dygyn" occupies a special place in the Yakut culture; it contributes to the formation of the Yakut national identity.

\subsection{The discourse of spoken and written sports reportings}

In mass media, conceptual metaphors are generally used due to their potential to provide vivid narratives and to highlight various aspects of a sporting event. For Crystal and Davy, spoken broadcasting differs from a written report in its live nature of the produced text; it is created spontaneously and without much premeditation. The guiding principles for commentators are, thus, to achieve fluency and retain audience interest [qtd. in 1, p. 34-35]. This attribute of the genre determines the extensive use of conceptual metaphors.

\section{National-cultural specificity of metaphorical conceptualization}

Conceptual metaphors are ubiquitous in language and thought because they help to understand abstract concepts through the use of more specific terms. A conceptual metaphor is "understanding and experiencing one kind of thing in terms of another" [2, p. 5]. Frozen metaphors are a part of everyday language, fixed correlations between source and target domains in our conceptual system.

Moreover, metaphorical conceptualization is a dynamic process that is characterized by different factors: sensorimotor, cultural, and linguistic experiences [3]. In everyday life, conceptual metaphors perform at least three cognitive functions: they structure our conceptual system, conceptualize abstract concepts in more understandable terms, and create a new understanding of our experience [4, p. 8]. This conceptual organization determines the generation of creative metaphors that can be extensions, elaborations, or combinations of conventional ones [5, p. 261].

For Kövecses, one of the contexts that influences the use of conceptual metaphors is a conceptual-cognitive context, which includes the metaphorical conceptual system in general, ideology, knowledge about past events, and interests and concerns of a community or an individual [qtd. in 6, p. 199]. Putz describes metaphorical conceptualization as a dynamic process in which the construction of new meanings and the reinterpretation of old ones are more similar among representatives of the same culture. The relationship

Corresponding author: fki110252@gmail.com 
between cognition and culture manifests itself in language [7, p. 9] and can help to reveal a typical conceptual system. In other words, a thorough study of the mechanisms of metaphorical conceptualization contributes to a better understanding of the national and cultural specificity of conceptual metaphors.

\section{Discussions}

\subsection{Metaphorical conceptualization in Russian- language national sports}

In the context below, we find the use of frozen metaphors which explains the sportsmen's actions:

(1) "Спортсмень буквально выходили ва-банк. Ставки были слишком высоки, чтобы ошибаться" IPA:/spert ' 'mieni bok'valinə vixe' ${ }^{\prime} \mathrm{djil}^{\mathrm{j}} \mathrm{j}_{\mathrm{I}}$ va bank stafk' ${ }^{j_{I}}$

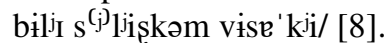

(1) Athletes literally went all-in. The stakes were too high to make a mistake.

The frozen metaphors ва-банк IPA:/va bank/ and ставки IPA:/stafk $\mathrm{k}_{\mathrm{I}} /$ are gambling metaphors (SPORT IS GAMBLING) and they focus readers' attention on a certain aspect of a sport event. "Ва-банк" has the following meaning in the dictionary: for all the money, risking everything [9]. The conceptual domains of gambling and sports competition share more or less similar frame structures: in both, the outcome of risk is victory or loss. In addition, professional sports and gambling are associated with great responsibility and the risk of failure - injury to the participants.

(2) Думаю, Байанай спорта дал мне время подумать. Ведь когда человек всё время побеждает, то он теряет истинный вкус победы и начинает расслабляться IPA:/duməju bеje'naj sportə dał mnje

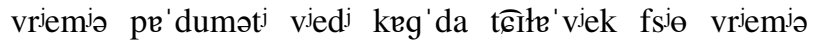

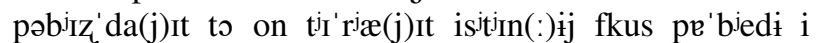
nətढิ' na(j)It rəs:łe'bliats:ə/ [8].

(2) I think Baianai of sports gave me time to think. After all, when a person wins all the time, he loses the true taste of victory and begins to relax.

In this context (2) we see the creative metaphor Байанай cnopma IPA:/beje'naj sportə/, which reflects the Yakut belief in the spirit of hunting - Baianai. In this case, special attention should be paid to the mechanism of creative metaphor generation: as in the traditional occupation of the Yakuts (hunting), the athlete is metaphorically helped by the spirit. The conceptual metaphor SPORT IS HUNTING is verbalized with Baianai. According to the Yakut mythology, Baianai notes and subsequently awards luck to generous hunters who share their success. In our opinion, the athlete metaphorically shares his "game" (prizes) with other "hunters" (participants) in order to be lucky in the future. (3) Все мои лучшие годы и вся моя молодость были

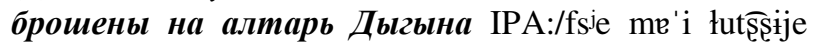

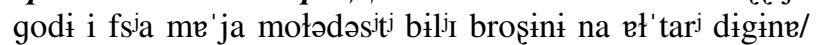
[10].

(3) All my best years and all my youth were thrown on the altar of Dygyn.
Here (3) we find the frozen metaphor of Russian

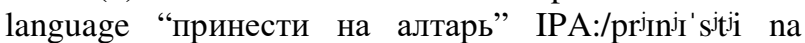
ef'tar/ (to put on the altar) used in a creative form thrown on the altar of Dygyn. This metaphor refers to the national sports tournament "The Games of Dygyn". Competitions are held annually on the day of the Ysyakh festival, which has been considered a sacred celebration of the Yakuts since ancient times. In this case, metaphorical conceptualization allows the author to convey the "sacred" meaning that the tournament has acquired for the athlete. Many years of hard training of the athlete are metaphorically compared to making a sacrifice on the altar in the form of constant training without leisure. This metaphorical usage in Russian sports discourse should not be confused with the English phrase "be sacrificed on the altar of something" with the following meaning in the dictionary: "to be destroyed by an activity, system, or belief that is bad but more important or more powerful" [11]. On the contrary, the Russian phrase "принести на алтарь" has no negative connotation and is marked as a poetic phrase [12].

We also see the extensive use of war metaphors, which conceptualize sport as war. For more clarity, let us present the basic metaphor of sports discourse SPORT IS WAR and its elaborations together:

(4) 24 боотура IPA:/botora/ [8, p. 5].

(4) 24 booturs.

(5) Сегодня мы стали очевидияами захватывающих

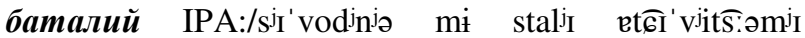
zex'vativəju6:Ix be'talijj/ [8, p. 5].

(5) Today we witnessed exciting fights.

(6) Как видишь, один в поле не воин. Нужен хороший тренер IPA:/kak vidis $\mathfrak{e}^{\prime} \mathrm{djin}^{\mathrm{f}}$ polje nje voIn nuzin xe' ${ }^{\prime}$ rosij trienirs/ [8, p. 7].

(6) As you can see, one warrior does not make a battle. A good coach is needed.

(7) Намские боотуры продолжают побеждать IPA:/namskije botori prədeł' zajut pəbj'IZ̨'dati/ [8, p. 11].

(7) Namsky booturs continue to win.

(8) Намские «универсальные солдаты» продолжают успешно выступать в якутском многоборье IPA:/namskije on' ${ }^{j}{ }^{j}{ }^{j}{ }^{\prime} r^{\prime}$ salinije sel'dati prədeł'zajot $\mho^{\prime}$ sppesn $^{\mathrm{j}}$ visto'pat $\mathrm{f}(\mathrm{j}) \mathrm{I}^{\prime}$ kutSkəm mnəge'borjje / [8, p. $11]$.

(8) Namsky "universal soldiers" continue to perform successfully in the Yakut multisport competition.

(9) Победителем же стал намский боотур Артём

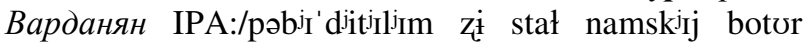

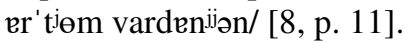

(9) And the winner was Namsky bootur Artem Vardanyan.

(10) И под конеи мы узнаем, готов ли он принять вызов на «Битву века» IPA:/i pot ke'njets mi

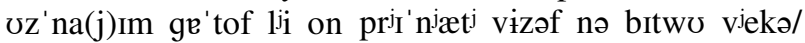
$[10$, p. 6].

(10) And at the end, we find out whether he is ready to accept the challenge of the "Battle of the century".

(11) Плох тот солдат, который не мечтает стать генералом IPA:/płox tot set'dat ke'torij $n^{\mathrm{j}} \mathrm{I} \mathrm{m}^{\mathrm{j}} \mathrm{It} \widehat{\mathrm{G}} \mathrm{ta}(\mathrm{j}) \mathrm{It}$ stat $^{\mathrm{j}} \mathrm{g}^{\mathrm{j}} \mathrm{In}_{\mathrm{I}}^{\mathrm{j}}{ }^{\mathrm{I}} \mathrm{rałəm} /[10, \mathrm{p} .6]$.

(11) A soldier who does not want to be a general is a bad soldier. 
(12) Сейчас победитель Игр Дыгына не только могучий и сильный боотур, но и всесторонне развитый спортсмен IPA:// $\mathrm{s}_{\mathrm{I}}{ }^{\prime}$ tढ̆

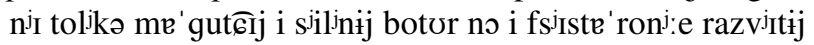
sperts mien/ [10, p. 7]...

(12) Now the winner of the Games of Dygyn is not only a mighty and strong bootur, but a well-rounded athlete.

(13) А битва титанов, это будет, как шоу IPA:/a bjitvə tis' tanəf ctə budist kak $\int \mathrm{ou} /[10, \mathrm{p} .7]$.

(13) And the battle of the titans, it will be like a show.

In these contexts, athletes are metaphorically understood as warriors (6), general (11), soldiers (8, 11), and booturs (ancient Yakut warriors) (4, 7, 9, 12). Sports competitions, in turn, are represented as fights (5) and battle $(10,11)$. As we can see in these Russian-language articles, the metaphor bootur is used extensively, which is determined by cultural and historical contexts. This metaphorical nomination is a more specific subcategory of the war metaphor: the warrior metaphor in sports discourse has a greater degree of conventionality and broader meaning than bootur. Thus, the authors of the regional sports newspaper consider the knowledge of Yakut readers, which contributes to the correct interpretation of figurative expressions and the achievement of a metaphorical effect.

\subsection{Metaphorical conceptualization in Yakut- language national sports}

In our opinion, creative metaphorical extensions in the Yakut language have unique and original cross-domain mappings between the source and target domains. In the contexts below, we also find the elaborations of the basic conceptual metaphor of sports discourse SPORT IS WAR [13]:

(14) '1 Kыmmblaxmapblн сөптөөхтөрун диэн дакаастаабыт улахан эрэ бухатыырдар IPA:/kuttuaxtarun søptøøxtøryn dien dakaastaabut ulaxan ere buxatuurdar/...

(14) Great bogatyrs who have proved that they can participate.

(15) ‘6 Николай Николаев кэнниттэн дьэ БүлҮY боотурдара IPA:/nikolaj nikolajev kennitten ృe bylyy booturdara/.

(15) After Nikolai Nikolaevich, finally the Vilyui booturs.

(16) '7 Николай Хоһуунай Матаннанов IPA:/nikolaj xohuunaj matannanov/.

(16) Nikolai Khohuunay Matannanov.

(17) '8 Дьулустаан Ноговицын... Таас Боотур диэн manтаан аaтmыbыбыт IPA:/ృulustaan nogovitsun taas bootur dien taptaan aattuubut/.

(17) Julustaan Nogovitsyn... Stone Bootur, we call him loving.

(18) '9 Эн сақана улахан бухатыырдар буоллақына, билигин эн курдук 74, 75, 80 киилэлээх уолаттар олус элбэхтэр IPA:/en sayana ulaxan buxatuurdar buollayuna biligin en kurduk kiileleex uolattar olus elbexter/.

(18) If there were big bogatyrs in your time, now there are a lot of guys weighing 74, 75, 80 kilograms.
(19) '34 Дыгын Оонньуутугар бастаабыт боотур биир мөлуйүөну илдьэ барыақа IPA:/dugun oonnuutugar bastaabut bootur biir mølyjyøny ilje baruaya/.

(19) Bootur, who will take first place in the Dygyn Games, will take one million with him.

In sports discourse on the material of the Yakut language, we also find metaphorical nominations related to the war: bogatyr $(14,18)$, bootur $(15,17,19)$, and Khohuunay.

In the above contexts $(14,18)$, Yakut athletes are metaphorically understood as “бухатыырдар" IPA:/buxatuurdar/ (ancient Yakut warriors, bogatyrs). These conceptual metaphors, in our opinion, refer to the characters of the heroic epos Olonkho who are known for their unusual strength and courage.

As we can see in the contexts $(15,17,19)$, athletes are also metaphorically presented as booturs - ancient Yakut warriors. The nicknames of the Yakut athletes Khohuunay (16) and Stone Bootur (17) deserve special attention for analysis. Khohuunay comes from the word khohuun, which in the northern and Vilyuysky District of Yakutia meant brave and courageous people, especially warriors and hunters [14]. Stone Bootur, in turn, metaphorically compares the sportsman's athletic build and endurance with him being a stone warrior. The characteristics of stone (for instance, firmness) are extrapolated to the participant of the competition. These conceptual metaphors are vivid figurative nominations that achieve expressiveness when describing sporting events.

(20) '5 АБатын муйаБын хатаран бу кэлэн эмиэ кыттара улахан эппиэтнэс дии саныbыblбын IPA:/ayatun tujayun xataran bu kelen emie kuttara ulaxan eppietnes dii sanuwbun/ [13]...

(20) I think it is a big responsibility that he follows in his father's footsteps and takes part again.

In the above context, we see the frozen metaphor туйабын хатар IPA:/tujayun xatar/, which has the following meaning in the dictionary: to be a worthy successor, heir to someone; a person who inherits someone's occupation (Yakutsk lit.: 'to dry someone's hooves') [15, p. 77]. This metaphoric usage shows the loss of meaning of figurative expression due to the difference in the metaphorical conceptualization of the previous generation. Kulakovskiy, one of the founders of the Yakut literature, notes that the etymology of the expression has its source in the custom of the Yakuts, according to which they keep the skulls and hooves of stallion and especially beloved horses in an inaccessible place [16, p. 107].

In our opinion, the above frozen metaphor is systematically connected to the conceptual metaphor LIFE IS JOURNEY. We find the following meaning of the phrase follow in someone's footsteps in the dictionary: "do as another person did before, especially in making a journey or following an occupation" [17]. Thus, the athlete metaphorically follows his father's journey (LIFE IS JOURNEY), i.e., his father's life/career as a professional athlete. The Yakut phrase to dry someone's hooves and the above English phrase have a similar meaning. Moreover, these metaphors take as a 
source domain the concepts related to parts of the leg: a foot and a hoof by which humans and animals make a "journey".

When describing cross-cultural variations in metaphorical conceptualization, Kövecses outlined the conceptual metaphor LIFE IS A PRECIOUS POSSESSION [5, p. 84]. It may be argued that the Yakut phrase metaphorically conceptualizes honoring someone's memory as cherishing a dear thing, a precious commodity. This interpretation of the metaphorical conceptualization of the previous generation corresponds to the above etymology given by Kulakovskiy. Thus, the phrase metaphorically understands remembering someone's life and following in their footsteps as taking care of, valuing, and admiring their hooves (LIFE IS A PRECIOUS POSESSION).

(21) '7 Владимир Фёдоров, Ньурба молодой ыччата, бөБө-та5а көрүннээх, тимир илиилээх, тимир amaxmaax IPA:/vladimir fjodorov nurba molodoj utftfata bøyø taya køryyneex timir iliileex timir ataxtaax/ [13].

(21) Vladimir Fedorov, a young man from Nyurba, of strong build, with an iron arm and an iron leg.

In this context (21), we see creative metaphors that describe the athlete's physical characteristics as having an iron arm and an iron leg. These metaphorical usages refer to his body as being made of iron. Iron is a strong, hard metal, much used as a material for construction and manufacturing [18, p. 923]. Thus, the athlete's arm and leg characteristics are metaphorically regarded as similar to the strength, firmness of iron.

(22) '8 Егор Филиппов... Хангалас хотойо... бэйэтин кепкатын кэппит... байанайдаах кепката IPA:/jegor filippov xayalas xotojo bejetin kepkatun keppit bajanajdaax kepkata/ [13].

(22) Egor Filippov... The Khangalassky eagle... wearing his cap... the cap with Baianai.

As we can see in the context above (22), the creative metaphor the khangalassky eagle is used. The athlete is metaphorically conceptualized as a large bird of prey an eagle. Moreover, an eagle is known for its powerful flight and keen sight. The athlete Egor Filippov is famous for his performance in jumping (which is metaphorically compared to an eagle's flight) and archery (the athlete's precision in which metaphorically compared to having an eagle's sight).

Moreover, we find the frozen metaphor with Baianai, which has the following meaning in the dictionary: someone with their Baianai who helps in hunting; lucky in hunting [19]. Therefore, this metaphorical usage is highly conventional (present in dictionaries) and realizes the conceptual metaphor SPORT IS HUNTING. The athlete's cap (head covering) is metaphorically conceptualized as bringing him luck in "hunting" (tournaments).

(23) '31 Егор Филиппов этин-сиинин көрдөххө, дьэ кырдыькк быйыл хара5а уота син умайан IPA:/jegor

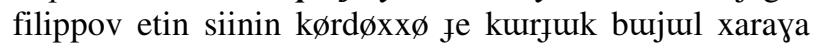
uota sin umajan/ [13].

(23) If we look at Egor Filippov's body, in fact, his eyes are fairly on fire this year.
In the context above (23), we see the frozen metaphor харақа уота умайан IPA:/хагауа uota umajan/. We find the following meaning of the Yakut word "yot" IPA:/uot/: inner burning, passion, fire (for example, of love) [20, p. 233]. Moreover, this word is used as a component in the Yakut phrase "уот курдук киһи" IPA:/uot kurduk kihi/ (Yakutsk lit.: 'a man like fire') with the following meaning: a person who stops at nothing, quick, and clever [Ibid., p. 236]. In the English language, in turn, we find the phrase "on fire" with the meaning: "very strong emotion, especially anger or enthusiasm" [21]. Thus, the conceptual metaphor in both languages expresses a person's emotional state. In the analyzed context (23), the athlete's performance is directly linked to the metaphorical fire in his eyes, which describes his psycho-emotional state, passion, and enthusiasm to win the tournament.

\section{Conclusions}

Conceptual metaphors achieve audience interest, evoke certain emotions and influence evaluations of a sporting event. The basic metaphor of sports discourse SPORT IS WAR is frequently extended by metaphorical nominations (bukhatyyr, soldaty, etc.). The specificity of the national sports tournament and its importance in the Yakut culture allows the authors and commentators to extensively conceptualize the Yakut athletes as national heroes - bogatyrs and booturs. In national sports, conceptual metaphors vividly and expressively reflect the specificity of not only the language, but also the history (bootur, Khohuunay), traditions (Agatyn tuyagyn khataran), and the metaphorical conceptualization of a particular ethnos (the Sakha). The national and cultural specificity of conceptual metaphors contribute to an easier perception for audience due to a similar conceptual-cognitive context with authors or commentators.

This research was funded by grant No. 075-15-2021-616 from the Government of the Russian Federation for the project «Preservation of Linguistic and Cultural Diversity and Sustainable Development of the Arctic and Subarctic of the Russian Federation».

\section{References}

1. J. Chovanec, The Discourse of Online Sportscasting (J.B.P.C., 2018)

2. G. Lakoff, M. Johnson, Metaphors We Live By (UCP, 2003)

3. E. Castaño, E. Gilboy, S. Feijóo, E. Serrat, C. Rostan, J. Hilferty, T. Cunillera, Cogn Sci, 42 (7), 2342-2363 (Wiley-Blackwell, 2018)

4. M. Zheng, A Conceptual Metaphor Account of Word Composition (CSP, 2017)

5. Z. Kövecses, Metaphor in Culture (CUP, 2005)

6. W. Xu, J.R. Taylor, The Routledge Handbook of Cognitive Linguistics (Routledge, 2021) 
7. O. Putz, Metaphor and National Identity (J.B.P.C., 2019)

8. Sport of Yakutia, 25 (0432) (2015)

9. S.A. Kuznetsov (Ed.), The Large Explanatory Dictionary of the Russian Language, Retrieved from http://www.gramota.ru/slovari/dic/?word=вабанк\&all=x

10. Sport of Yakutia, 41 (0448) (2015)

11. Cambridge Advanced Learner's Dictionary \& Thesaurus, Retrieved from https://dictionary.cambridge.org/dictionary/english/b e-sacrificed-on-the-altar-of-sth

12. T. Volkova (Ed.), The Phraseological Dictionary of the Russian Language Retrieved from https://phrasebook_ru.academic.ru/19/алтарь

13. The Games of Dygyn (1st day, 4th part, (2021), Retrieved from https://www.youtube.com/watch?v=Ycau-

PSKZEg\&list=PL19ZwiAmfPfh5JTTR2DEDrd3Wj UusI1KJ\&index $=4$

14. N.A. Nikolaev, Young Scientist, 20 (79), 33-34 (2014)

15. P.A. Sleptsov (Ed.), Large Explanatory Dictionary of the Yakut Language, Vol. 11 (Nauka, Novosibirsk, 2014)

16. A.E. Kulakovskiy, Scholarly works (Yak. Publ. House, Yakutsk, 1979)

17. J. Ayto (Ed.), The Oxford Dictionary of English Idioms (3 ed.), (OUP, 2009), Retrieved from https://www.oxfordreference.com/view/10.1093/acr ef/9780199543793.001.0001/acref-9780199543793e-966

18. A. Stevenson (Ed.), Oxford Dictionary of English (OUP, Oxford, 2010)

19. P.A. Sleptsov (Ed.), Large Explanatory Dictionary of the Yakut Language, Vol. 2 (Nauka, Novosibirsk, 2005)

20. P.A. Sleptsov (Ed.), Large Explanatory Dictionary of the Yakut Language, Vol. 13 (Nauka, Novosibirsk, 2016)

21. Oxford Advanced Learner's Dictionary, accessed Retrieved from https://www.oxfordlearnersdictionaries.com/definiti on/english/fire_1 